\title{
SISTEM PENDUKUNG KEPUTUSAN UNTUK MENENTUKAN PENERIMA BEASISWA KURANG MAMPU MENGGUNAKAN METODE SAW
}

\author{
Uji Muchariroh \\ Program Studi Teknik Informatika \\ STMIK Mitra Lampung \\ J1. ZA. Pagaralam No. 7, Gedungmeneng, Gedong Meneng, \\ Rajabasa, Kota Bandar Lampung, Lampung 40115 \\ Email : ujimuchariroh@yahoo.com
}

\begin{abstract}
ABSTRAK
Banyaknya pemohon beasiswa, menjadi tantangan tersendiri bagi pihak pengelola lembaga pendidikan untuk dapat memberikan suatu keputusan yang tepat, efektif dan efisien dalam pengelolaan data penerima besiswa yang benar-benar berhak menerima beasiswa,Dalam menentukan penerimaan beasiswa kurang mampu, banyak sekali kriteria-kriteria yang harus dimiliki oleh individu sebagai syarat dalam mendapatkan beasiswa. Masing-masing universitas pasti memiliki kriteria-kriteria untuk menentukan siapa yang akan terpilih untuk menerima beasiswa. Pembagian beasiswa dilakukan untuk membantu seseorang yang kurang mampu secara ekonomi selama menempuh studinya. Untuk membantu penentuan dalam menetapkan seseorang yang layak menerima beasiswa maka dibutuhkan sebuah sistem pendukung keputusan.Pada penelitian ini akan diangkat suatu kasus yaitu mencari alternative terbaik bedasarkan kriteria-kriteria yang telah ditentukan dengan menggunakan metode SAW (Simple Additive Weighting) Penelitian dilakukan dengan mencari nilai bobot untuk setiap atribut, kemudian dilakukan proses perankingan yang akan menentukan alternatif yang optimal, yaitu siswa terbaik.
\end{abstract}

Kata Kunci : sistem rekomendasi, beasiswa, SAW

\section{PENDAHULUAN}

\subsection{Latar Belakang}

Institusi pendidikan saat ini banyak membuka peluang beasiswa bagi siswa yang kurang mampu. Dengan semakin banyaknya pemohon beasiswa, menjadikan tantangan tersendiri bagi pihak pengelola untuk dapat memberikan suatu keputusan yang tepat, efektif dan efisien dalam pengelolaan data penerima besiswa yang benar-benar berhak menerima beasiswa.

Saat ini pengelola lembaga masih menggunakan cara manual untuk menetukan peserta didik baru yang berhak menerima beasiswa. Sehingga pengolahan data kurang efektif, membutuhkan waktu yang relatif lama dan sering terjadi subjektifitas dari para pengambil keputusan.

Untuk mendapatkan beasiswa tersebut maka harus sesuai dengan aturan-aturan yang telah ditetapkan. Kriteria yang ditetapkan dalam studi kasus ini adalah Penghasilan Orang Tua, Jumlah Saudara Kandung, Tanggungan Orangtua, Kepemilikan Rumah dan Indeks Prestasi. Oleh sebab itu tidak semua yang mendaftarkan diri sebagai calon penerima beasiswa tersebut akan diterima, hanya yang memenuhi kriteriakriteria saja yang akan memperoleh beasiswa tersebut.

Untuk mempermudah para pengurus dalam menentukan peserta didik baru yang berhak menerima beasiwa, maka perlu adanya suatu sistem rekomendasi yang berfungsi untuk membantu melakukan seleksi kepada para calon penerima beasiswa. Sistem rekomendasi pemberian beasiswa adalah suatu sistem yang berfungsi membantu tim penyeleksi dalam melakukan penyeleksian terhadap para calon penerima beasiswa menggunakan metode $S A W$ (Simple Additive Weighting).

Model yang digunakan dalam sistem pendukung keputusan ini adalah $S A W$, karena $S A W$ ini dipilih karena dapat menentukan nilai bobot untuk setiap atribut, kemudian dilanjutkan dengan proses perankingan 
yang akan menyeleksi alternatif terbaik dari sejumlah alternatif, dalam hal ini alternatif yang dimaksud adalah yang berhak menerima beasiswa berdasarkan kriteria-kriteria yang ditentukan.

Dengan metode perangkingan tersebut, diharapkan penilaian akan lebih tepat karena didasarkan pada nilai kriteria dan bobot yang sudah ditentukan sehingga akan mendapatkan hasil yang lebih akurat terhadap siapa yang akan menerima beasiswa tersebut

\subsection{Perumusan Masalah}

Berdasarkan uraian latar belakang diatas, terdapat rumusan masalah sebagai berikut: Bagaimana membuat Sistem Pendukung Keputusan menggunakan Metode SAW (Simple Additive Weighting) yang dapat membantu dalam pemilihan calon penerima program beasiswa kurang mampu yang tepat dan akurat.

\subsection{Ruang Lingkup Penelitian}

Ruang lingkup permasalahan yang akan diteliti untuk menghindari meluasnya masalah, dibatasi pada :

1. Pembuatan Sistem Pendukung Keputusan menggunakan Metode SAW pada penelitian ini hanya digunakan untuk menentukan calon penerima program beasiswa kurang mampu

2. Variabel yang terdapat dalam penentuan calon siswa penerima program bina lingkungan adalah (1) Penghasilan Orang Tua (2) Jumlah Saudara Kandung (3) Tanggungan Orangtua (4) Kepemilikan Rumah (5) Indeks Prestasi

\subsection{Tujuan Penelitian}

Tujuan penulisan tesis ini adalah untuk menerapkan metode SAW (Simple Additive Weighting untuk membuat suatu keluaran sistem berupa rekomendasi calon siswa yang berhak menerima program bina lingkungan.

\subsection{Manfaat Penelitian}

Berdasarkan tujuan penelitian diatas, manfaat dari penelitian ini yaitu :

1. Memberikan kontribusi positif bagi pembangunan dunia pendidikan agar program beasiswa kurang mampu bisa tepat sasaran.

2. Membantu tim penyeleksi dalam menentukan calon penerima yang berhak mendapatkan program beasiswa kurang mampu sesuai dengan kriteria yang telah ditetapkan.

\section{LANDASAN TEORI}

\subsection{Sistem Pendukung Keputusan}

Konsep Sistem Pendukung Keputusan diperkenalkan pertama kali oleh Michael S. Scoott Morton pada tahun 1970-an dengan istilah Management Decision System, SPK dirancang untuk mendukung seluruh tahap pengambilan keputusan mulai dari mengidentifikasi masalah, memilih data yang relevan, dan menentukan pendekatan yang digunakan dalam proses pengambilan keputusan, sampai mengevaluasi pemilihan alternatif (Sprague, 1982).

Sistem pendukung keputusan adalah sistem penghasil informasi yang ditujukan pada suatu masalah tertentu yang harus dipecahkan oleh manager dan dapat membantu manager dalam pengambilan keputusan (Raymond Mc Leod, Jr., 1995:348). Sistem pendukung keputusan merupakan bagian tak terpisahkan dari totalitas sistem organisasi keseluruhan. Suatu sistem organisasi mencakup sistem fisik, sistem keputusan dan sistem informasi (Dr. Ir. Kadarsyah Suryadi, 2002:13).

Sistem pendukung keputusan adalah suatu pendekatan sistematis pada hakekat suatu masalah, pengumpulan fakta-fakta penentu yang matang dari alternatif yang dihadapi dan pengambilan tindakan yang paling tepat (Kadarsih Suryadi, 2000:1). Sistem pendukung keputusan adalah suatu sistem berbasis komputer yang menghasilkan berbagai alternatif keputusan untuk membantu manajemen dalam menangani berbagai permasalahan yang terstruktur ataupun tidak terstruktur dengan menggunakan data dan model (Dadan Umar Daihani, 2001:55). Untuk menghasilkan keputusan yang baik di dalam sistem pendukung keputusan, perlu didukung oleh informasi dan fakta-fakta yang berkualitas antara lain :

a. Aksebilitas

Atribut ini berkaitan dengan kemudahan mendapatkan informasi, informasi akan lebih berarti bagi si pemakai kalau informasi tersebut mudah didapat, karena akan berkaitan dengan aktifitas dari nilai informasinya.

b. Kelengkapan 
Atribut ini berkaitan dengan kelengkapan isi informasi, dalam hal ini isi tidak menyangkut hanya volume tetapi juga kesesuaian dengan harapan si pemakai sehingga sering kali kelengkapan ini sulit diukur secara kuantitatif.

c. Ketelitian

Atribut ini berkaitan dangan tingkat kesalahan yang mungkin di dalam pelaksanaan pengolahan data dalam jumlah (volume) besar. Dua tipe kesalahan yang sering terjadi yaitu berkaitan dengan perhitungan.

d. Ketepatan

Atribut ini berkaitan dengan kesesuaian antara informasi yang dihasilkan dengan kebutuhan pemakai. Sama halnya dengan kelengkapan, ketepatan pun sangat sulit diukur secara kuantitatif.

e. Ketepatan Waktu

Kualitas informasi juga sangat ditentukan oleh kektepatan wktu penyampaian dan aktualisasinya. Misal informasi yang berkaitan dengan perencanaan harian akan sangat berguna kalau disampaikan setiap dua hari sekali.

f. Kejelasan

Atribut ini berkaitan dengan bentuk atau format penyampaian informasi. Bagi seorang pimpinan, informasi yang disajikan dalam bentuk grafik, histogram, atau gambar biasanya akan lebih berarti dibandingkan dengan informasi dalam bentuk kata-kata yang panjang.

g. Fleksibilitas

Atribut ini berkaitan dengan tingkat adaptasi dari informasi yang dihasilkan terhadap kebutuhan berbagai keputusan yang akan diambil dan terhadap sekelompok pengambil keputusan yang berbeda.

\subsubsection{Tahapan Pengambilan keputusan}

Untuk menghasilkan keputusan yang baik ada beberapa tahapan proses yang harus dilalui dalam

pengambilan keputusan. Menurut Julius Hermawan (2002:3), proses pengambilan keputusan melalui beberapa tahap berikut :

1. Tahap Penelusuran(intelligence)

Tahap ini pengambil keputusan mempelajari kenyataan yang terjadi, sehingga kita bisa mengidentifikasi masalah yang terjadi biasanya dilakukan analisis dari sistem ke subsistem pembentuknya sehingga didapatkan keluaran berupa dokumen pernyataan masalah.

2. Tahap Desain

Dalam tahap ini pengambil keputusan menemukan, mengambangkan dan menganalisis semua pemecahan yang mungkin yaitu melalui pembuatan model yang bisa mewakili kondisi nyata masalah. Dari tahapan ini didapatkan keluaran berupa dokumen alternatif solusi.

3. Tahap Choice

Dalam tahap ini pengambil keputusan memilih salah satu alternatif pemecahan yang dibuat pada tahap desain yang dipandang sebagai aksi yang paling tepat untuk mengatasi masalah yang sedang dihadapi. Dari tahap ini didapatkan dokumen solusi dan rencana implementasinya.

4. Tahap Implementasi

Pengambil keputusan menjalankan rangkaian aksi pemecahan yang dipilih di tahap choice. Implementasi yang sukses ditandai dengan terjawabnya masalah yang dihadapi, sementara kegagalan ditandai masih adanya masalah yang sedang dicoba untuk diatasi. Dari tahap ini didapatkan laporan pelaksanaan solusi dan hasilnya.

\subsubsection{Komponen-Komponen Sistem Pendukung Keputusan}

Sistem pendukung keputusan terdiri dari 3 komponen utama atau subsistem yaitu (Dadan Umar Daihani, 2001:63) :

a. Subsistem Data (Database)

Subsistem data merupakan komponen sistem pendukung keputusan penyedia data bagi sistem. Data dimaksud disimpan dalam suatu pangkalan data (database) yang diorganisasikan suatu sistem yang disebut sistem manajemen pengkalan data (Data Base Manajemen System/DBMS).

b. Subsistem Model (Model Subsistem)

c. Subsistem Dialog (User Sistem Interface) 
Keunikan lainnya dari sistem pendukung keputusan adalah adanya fasilitas yang mampu mengintegrasikan sistem terpasang dengan pengguna secara interaktif. Fasilitas yang dimiliki oleh subsistem ini dapat dibagi atas 3 komponen yaitu :

a. Bahasa aksi (Action Language) yaitu suatu perangkat lunak yang dapat digunakan pengguna untuk berkomunikasi dengan sistem. Komunikasi ini dilakukan melalui berbagai pilihan media seperti keyboard, joystick dan key function.

b. Bahasa Tampilan (Display atau Presentation Language) yaitu suatu perangkat yang berfungsi sebagai sarana untuk menampilkan sesuatu.

c. Basis Pengetahuan (Knowledge Base) yaitu bagian yang mutlak diketahui oleh pengguna sistem yang dirancang dapat berfungsi secara efektif.(Umar Daihani, 2000:63)

\subsection{Metode SAW}

Metode SAW sering juga dikenal istilah metode penjumlahan terbobot. Konsep dasar metode SAW adalah mencari penjumlahan terbobot dari rating kinerja pada setiap alternatif pada semua atribut. Metode SAW membutuhkan proses normalisasi matriks keputusan $(\mathrm{X})$ ke suatu skala yang dapat diperbandingkan dengan semua rating alternatif yang ada.

Metode SAW sering juga dikenal istilah metode penjumlahan terbobot. Konsep dasar metode SAW adalah mencari penjumlahan terbobot dari rating kinerja pada setiap alternatif pada semua atribut. Metode SAW membutuhkan proses normalisasi matriks keputusan $(\mathrm{X})$ ke suatu skala yang dapat diperbandingkan dengan semua rating alternatif yang ada.

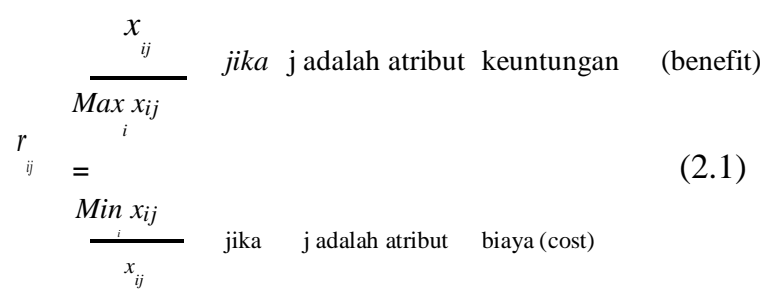

dimana $\mathrm{r}_{\mathrm{ij}}$ adalah rating kinerja ternormalisasi dari

alternatif $\mathrm{A}_{\mathrm{i}}$ pada atribut $\quad \mathrm{C}_{\mathrm{j}} ; \mathrm{i}=1,2, \ldots, \mathrm{m}$ dan $\mathrm{j}=1,2, \ldots, \mathrm{n}$.

Nilai Preferensi untuk setiap alternatif (Vi)diberikan sebagai:

$$
V_{i}=\sum_{j=1} w_{j} r_{i j}
$$

Nilai $V_{i}$ yang lebih besar mengindikasikan bahwa alternatif $A_{i}$ lebih terpilih.

\section{METODOLOGI PENELITIAN}

\subsection{Metode pengumpulan Data}

a. Wawancara / Interview

b. Studi Pustaka (Library Research Method)

\subsection{Indikator}

Indikator adalah suatu ukuran tidak langsung dari suatu kondisi. Indikator adalah variabel yang membantu kita dalam mengukur perubahan perubahan yang terjadi baik secara langsung maupun secara tidak langsung. Indikator disini yaitu variabel awal syarat calon penerima program beasiswa kurang mampu, dan pada sistem yang akan dirancang ada berbagai indikator antara lain :

(1) Penghasilan Orang Tua (2) Jumlah Saudara Kandung (3) Tanggungan Orangtua (4) Kepemilikan Rumah (5) Indeks Prestasi

\subsection{Data Kriteria}

Data Kriteria yang berisi kode, nama, atribut, bobot. Bobot kriteria menentukan seberapa penting kriteria tersebut. Atribut kriteria terdiri dari benefit atau cost, dimana benefit artinya semakin besar nilainya semakin bagus, sedangkan cost semakin kecil nilainya semakin bagus. 


\begin{tabular}{|l|l|l|c|}
\hline $\begin{array}{l}\text { Kode } \\
\text { Kriteria }\end{array}$ & Nama Kriteria & Atribut & Bobot \\
\hline C1 & Penghasilan Orang Tua & Cost & 30 \\
\hline C2 & Jumlah Saudara Kandung & Benefit & 15 \\
\hline C3 & Tanggungan Orangtua & Benefit & 10 \\
\hline C4 & Kepemilikan Rumah & Benefit & 25 \\
\hline C5 & Indeks Prestasi & Benefit & 20 \\
\hline
\end{tabular}

Dari 5 kriteria tersebut hanya penghasilan orang tua yang menjadi atribut cost, karena semakin besar penghasilan orang tua, maka semakin kecil kesempatan terpilih

\subsection{Data Cript}

\begin{tabular}{|l|l|l|l|}
\hline $\begin{array}{l}\text { Kode } \\
\text { Kriteria }\end{array}$ & Nama Kriteria & Crips & Nilai \\
\hline C1 & Penghasilan Orang Tua & $\begin{array}{l}\text { Rp.0- } \\
1.999 .999\end{array}$ & 40 \\
\hline C1 & Penghasilan Orang Tua & $\begin{array}{l}\text { Rp.2.000.000- } \\
2.999 .999\end{array}$ & 60 \\
\hline C1 & Penghasilan Orang Tua & $\begin{array}{l}\text { Rp.3.000.000- } \\
3.999 .999\end{array}$ & 80 \\
\hline C1 & Penghasilan Orang Tua & $>$ Rp.4.000.000 & 100 \\
\hline C2 & Jumlah Saudara Kandung & 1 Orang & 40 \\
\hline C2 & Jumlah Saudara Kandung & $2-3$ Orang & 60 \\
\hline C2 & Jumlah Saudara Kandung & $4-5$ Orang & 80 \\
\hline C2 & Jumlah Saudara Kandung & $>5$ Orang & 100 \\
\hline C3 & Tanggungan Orangtua & 1 Orang & 40 \\
\hline C3 & Tanggungan Orangtua & $2-3$ Orang & 60 \\
\hline C3 & Tanggungan Orangtua & $4-5$ Orang & 80 \\
\hline C3 & Tanggungan Orangtua & $>5$ Orang & 100 \\
\hline C4 & Kepemilikan Rumah & $\begin{array}{l}\text { Milik Pribadi, } \\
54 \text { m2 }\end{array}$ & 40 \\
\hline C4 & Kepemilikan Rumah & $\begin{array}{l}\text { Milik Pribadi, } \\
45 \text { m2 }\end{array}$ & 60 \\
\hline C4 & Kepemilikan Rumah & $\begin{array}{l}\text { Milik Pribadi, } \\
36 \text { m2 }\end{array}$ & 80 \\
\hline C4 & Kepemilikan Rumah & Sewa & 100 \\
\hline C5 & Indeks Prestasi & $2.00-2.49$ & 40 \\
\hline C5 & Indeks Prestasi & $2.50-2.99$ & 60 \\
\hline C5 & Indeks Prestasi & $8.01-3.49$ \\
\hline C5 & Indeks Prestasi & 100 \\
\hline
\end{tabular}

\subsection{Data Alternatif}

Data Alternatif merupakan alternatif yang akan dihitung nilainya dan dipilih sebagai alternatif terbaik. Data alternatif biasanya berisi kode dan nama. Berdasarkan studi kasusnya pemberian kredit, maka data alternatif adalah data calon yang mengajukan kredit.

\begin{tabular}{|l|l|}
\hline Kode & Nama \\
Alternatif & Alternatif \\
\hline
\end{tabular}




\begin{tabular}{|l|l|}
\hline A1 & Si A \\
\hline A2 & Si B \\
\hline A3 & Si C \\
\hline A4 & Si D \\
\hline
\end{tabular}

\section{Perhitungan SAW}

Setelah menyiapkan data, sekarang waktunya melakukan perhitungan SAW yang kita bagi menjadi 3 langkah yaitu:

\subsection{Tahap Analisa}

Pada tahap ini anda mengubah nilai pada alternatif sesuai bobot pada data crips, sehingga diperoleh data seperti tabel berikut:

\begin{tabular}{|c|c|c|c|c|c|}
\hline & C1 & C2 & C3 & C4 & C5 \\
\hline A1 & 40 & 100 & 60 & 80 & 40 \\
\hline A2 & 60 & 80 & 100 & 80 & 60 \\
\hline A3 & 80 & 80 & 80 & 60 & 60 \\
\hline A4 & 60 & 60 & 80 & 40 & 60 \\
\hline
\end{tabular}

\subsection{Tahap Normalisasi}

Untuk melakukan normalisasi tabel pada tahap analisa, kita perlu memahami rumus berikut:

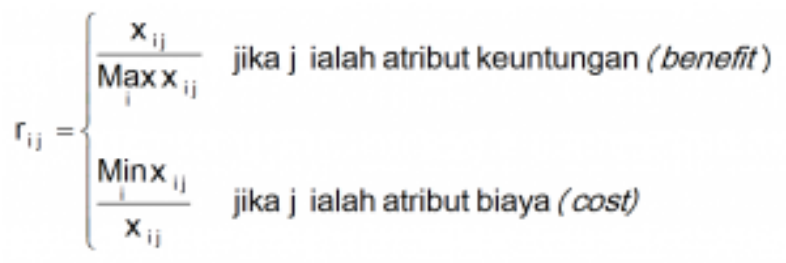

Penjelasan:

- benefit, setiap elemen matriks dibagi dengan max dari baris matriks

- cost, min dari kolom matriks dibagi dengan setiap elemen matriks.

Untuk kriteria $C 1$, karena cost, maka kita cari $\min (40,60,80,60)=40$. Sehingga untuk:
$\mathrm{A} 1=40 / 40=1$
$\mathrm{A} 2=40 / 60=0.67$
$\mathrm{A} 3=40 / 80=0.5$
$\mathrm{A} 4=40 / 60=0.67$

Untuk kriteria C2, karena benefit, maka kita cari $\max (100,80,80,60)=100$. Sehingga untuk:
$\mathrm{A} 1=100 / 100=1$
$\mathrm{A} 2=80 / 100=0.8$
$\mathrm{A} 3=80 / 100=0.8$
$\mathrm{A} 4=60 / 100=0.6$

Untuk kriteria C3, karena benefit, maka kita cari $\max (60,100,80,80)=100$. Sehingga untuk:

$\mathrm{A} 1=60 / 100=0.6$

$\mathrm{A} 2=100 / 100=1$ 
$\mathrm{A} 3=80 / 100=0.8$

$\mathrm{A} 4=80 / 100=0.8$

Untuk kriteria $\mathrm{C} 4$, karena benefit, maka kita cari $\max (80,80,60,40)=80$. Sehingga untuk:
$\mathrm{A} 1=80 / 80=1$
$\mathrm{A} 2=80 / 80=1$
$\mathrm{A} 3=60 / 80=0.75$
$\mathrm{A} 4=40 / 80=0.5$

Untuk kriteria C5, karena benefit, maka kita cari $\max (40,60,60,60)=60$. Sehingga untuk:
$\mathrm{A} 1=40 / 60=0.67$
$\mathrm{A} 2=60 / 60=1$
$\mathrm{A} 3=60 / 60=1$
$\mathrm{A} 4=60 / 60=1$

\begin{tabular}{|c|c|c|c|c|c|}
\hline & C1 & C2 & C3 & C4 & C5 \\
\hline A1 & 1 & 1 & 0.6 & 1 & 0.67 \\
\hline A2 & 0.67 & 0.8 & 1 & 1 & 1 \\
\hline A3 & 0.5 & 0.8 & 0.8 & 0.75 & 1 \\
\hline A4 & 0.67 & 0.6 & 0.8 & 0.5 & 1 \\
\hline
\end{tabular}

\subsection{Tahap Perangkingan}

Pada tahap perangkingan, kita mengalikan bobot kriteria dengan setiap baris matriks nilai normalisasi.

Contoh untuk alternatif A1

$\mathrm{A} 1=(1 * 30)+(1 * 15)+(0.6 * 10)+(1 * 25)+(0.67 * 20)=89.4$

$\mathrm{A} 2=(0.67 * 30)+(0.8 * 15)+(1 * 10)+(1 * 25)+(1 * 20)=87.1$

$\mathrm{A} 3=(0.5 * 30)+(0.8 * 15)+(0.8 * 10)+(0.75 * 25)+(1 * 20)=73.75$

$\mathrm{A} 4=(0.67 * 30)+(0.6 * 15)+(0.8 * 10)+(0.5 * 25)+(1 * 20)=69.6$

dimana 1, 1, 0.6, 1, 0.67 ada hasil normalisasi dari alternatif A1, dan 30,15,10,25,20 adalah bobot dari masing masing kriteria.

Sehingga jika dilakukan hal yang sama untuk alternatif yang lain hasilnya akan seperti berikut:

\begin{tabular}{|l|c|c|c|c|c|l|l|}
\hline Bobot & C1 & C2 & C3 & C4 & C5 & & \\
\cline { 2 - 6 } & 30 & 15 & 10 & 25 & 20 & Total & Rank \\
\hline A1 & 0.8 & 1 & 0.6 & 1 & 0.67 & 89.4 & 1 \\
\hline A2 & 0.75 & 0.8 & 1 & 1 & 1 & 87.1 & 2 \\
\hline A3 & 1 & 0.8 & 0.8 & 0.75 & 1 & 73.75 & 3 \\
\hline A4 & 0.75 & 0.6 & 0.8 & 0.5 & 1 & 69.6 & 4 \\
\hline
\end{tabular}

Dari hasil perangkingan dapat dilihat alternatif A1 mendapat nilai terbesar yaitu 89.4 sehingga menjadi rank 1 (alternatif terbaik). 
Sistem Pendukung Keputusan Pemilihan Calon Penerima Program beasiswa kurang mampu Menggunakan Metode SAW dapat disimpulkan sebagai berikut ini :

1. Menghasilkan suatu sistem pendukung keputusan yang dapat membantu Tim penyeleksi dalam pemilihan calon penerima Program beasiswa kurang mampu

2. Dengan menggunakan SAW sebagai metode yang dapat membantu Tim penyeleksi untuk mempermudah menentukan calon penerima Program beasiswa kurang mampu.

3. Hasil keluaran dari sistem pendukung keputusan adalah perangkingan calon siswa yang paling berhak mendapatkan program beasiswa kurang mampu

4. Sistem pendukung keputusan dengan menggunakan metode SAW memberi nilai secara tepat sasaran bagi calon penerima yang paling berhak mendapatkan program beasiswa kurang mampu

\subsection{Saran}

Saran yang dapat diberikan penulis untuk pengembangan selanjutnya yaitu:

1. Pengembangan dari sistem pendukung keputusan selanjutnya sebaiknya dengan penambahan metode lainnya. Karena membutuhkan metode yang menyediakan arah yang khusus dalam pembobotan.

2. Penelitian selanjutnya disarankan dapat menambahkan web agar lebih mudah diakses oleh Tim Penyeleksi 


\section{DAFTAR PUSTAKA}

Daihani, Dadan Umar. 2001. Komputerisasi Pengambilan keputusan. Jakarta: Elex Media Komputindo.

Eniyati, Sri. 2011. Perancangan Sistem Pendukung Pengambilan Keputusan untuk Penerimaan Beasiswa dengan Metode SAW (Simple Additive Weighting). Jurnal Teknologi Informasi DINAMIK Volume 16, No.2, Juli $2011: 160170$

Hicks, James O. \& Leininger, Wayne E. 1986. Accounting Information Systems. Minnesota: West Publishing Co.

Hwang, C.L. \& Yoon, K. 1981. Multiple Attribute Decision Making: Methods and applications, New York: Springer-Verlag.

Kosasi, Sandy. 2002. "Sistem Penunjang Keputusan (Decision Support System)." Pontianak: Sekolah Tingg i Manajemen Informatika dan Komputer.

Moscove, Stephen A. \& Simkin, Mark G. 1984. Accounting Information Sistems Concepts and Practice for Effective Decision Making, second edition. New York: John Willey and Sons.

O'Brien, James A. 2005. Introduction to Information System, 12th edition. (Pengantar Sistem Informasi Perspektif Bisnis dan Manajerial. Jakarta: PT Salemba Empat (Emban Patria).

Sprague, R.H. \& Carlson, E.D., 1982. Building Effective Decision Support Systems. Englewood Cliffs, N.J.: Prentice Hall.

Supriyanto, Aji. 2005. Pengantar Teknologi Informasi. Jakarta: Salemba Infotek.

Suryadi, Kadarsah \& Ramdhani, M.Ali. 1998. Sistem Pendukung keputusan. Bandung : PT Remaja Rosdakarya.

Suryadi, Kadarsah \& Ramdhani, M.Ali. 2000 "Sistem Pendukung Keputusan suatu wacana structural idealisasi dan implementasi konsep pengambilan keputusan” Bandung: PT Remaja Rosdakarya. Edisi kedua.

Sutanta, Edhy. 2003. Sistem Informasi Manajemen. Yogyakarta: Graha Ilmu.

Sutopo, Hendayat. 1982. Pengantar Operasional Administrasi Pendidikan, Surabaya: Usaha Nasional.

Sutabri, Tata. 2005. Sistem Informasi Manajemen. Yogyakarta: Andi.

Turban, E, Aronson, Jay E \& Liang, Teng-Ping 2005. Decision Support Systems and Intelligent Systems $7^{\text {th }}$ $E d$. New Jersey : Pearson Education.

Turban, Efraim. 2005. Decision Support Systems and Intelegent Systems $5^{\text {th }}$ Edition. Canada: Printice-hall International.

Verzello, Robert J. \& Reuter II, John. 1982. Data Processing: Systems and Concepts. Tokyo: McGraw-Hill Kogakusha, Ltd.

Zeleny, M. 1982. Multiple Criteria Decision Making, 2 ed. New York: McGrawHill. 